IJAMSR 3 (6) www.ijamsr.com CrossRef: https://doi.org/10.31426/ijamsr.2020.3.6.3413

\title{
ECO-CRITICISM IN THE SHORT STORIES OF RUSKIN BOND: A CRITICAL STUDY
}

\author{
Dr. Govindappa \\ Asst. Professor, Dept. of. English, Sri Lakshmi Group of Institutions, Bangalore, India \\ Email: drgovind123@gmail.com
}

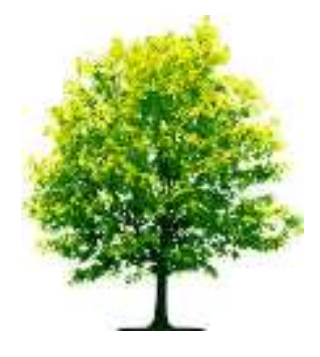

Keywords:

Ruskin Bond,

Environment,

Eco-criticism,

Ecology

\section{A B S T RA C T}

Literature is notable for reflecting contemporary issues and it is this spirit of concern and its reflection in literature that has offered ascend to another slice of literary speculation, in particular "Eco-criticism". Environmental concerns and publications linked to its impact individuals over the globe, the macrocosm. Eco-criticism is environmental activism that audits the human instinct association. Ruskin Bond is a productive author whose short stories for kids are found to have a profound understanding into a few parts of human instinct just as Nature all in all. Bond experienced childhood in Dehradun among trees, birds, and animals. Thus, his short stories and ballads possess large amounts of representations and symbolisms acquired from Nature. This paper takes a gander at the Ecological Concern in Ruskin Bond picked short stories.

Citation: Dr. Govindappa (2020). Eco-Criticism In The Short Stories Of Ruskin Bond: A Critical Study. International Journal of Advanced Multidisciplinary Scientific Research (IJAMSR) ISSN:2581-4281, 3 (6), June 2020, Pp 21 - 30 
IJAMSR 3 (6) www.ijamsr.com CrossRef: https://doi.org/10.31426/ijamsr.2020.3.6.3413

\section{International Journal of}

Advanced Multidisciplinary Scientific Research (IJAMSR) ISSN:2581-4281

\section{Introduction}

Ruskin Bond, up to standing Indian author who squats in the Himalayan town of Mussoorie, is panegyrized as an essayist, short story essayist, artist, and author for kids, teenagers, and adults. The enormous hearted, veteran author is the 'Pride of India'. He was not charmed towards Mussoorie as a town, yet rather to the surroundings slopes, timberlands and streams, or may be to the individuals from the villages.

Bond experienced childhood in Dehradun among trees, birds, animals, and insects of numerous types. Along these lines, his short stories and poems possess large amounts of metaphors and symbolisms obtained generously from Nature. His stories observe and contemplate the symbiotic connection among man and Nature.

Eco-criticism, a significant articulation made by Cheryll Glotfelty, the author of the American Association for Literature and Environment (ASLE), depicts the focal point of eco-criticism in the accompanying terms:

"While in most literary theory 'the world' is synonymous with society - the social sphereeco-criticism expands the notion of 'the world' to include the entire ecosphere."
His short stories oversee various pieces of locale from characteristic brilliance to late environmental pollution. Ecological disproportion and environmental corruption has transformed into a subject of phenomenal worry in today and the need of extraordinary noteworthiness is that people should get a handle on and moreover discover a reaction for this broad overall ecological emergency. H.J. McCloskey in his book Ecological Ethics and Politics an emergency that undermines not just the individual satisfaction to be made some incredible memories by human animals yet the plain endurance of mankind; that ecology uncovers that Homo sapiens are, or are in danger of transforming into, an endangered species; and itself and for its people, including humankind.

The turning of the interesting eminence around us is entwined purposely into an eco-critical work. An eco-critic has an eye sweeping and entering, a premonition that cautions the pursuers about the moving toward destruction that man's mercilessness has propositioned. The sagacious importance of such essayists and their immense stunning duty guides us to a wondrous exchange of ordinary and private being changed over into continuing general 
IJAMSR 3 (6) www.ijamsr.com CrossRef: https://doi.org/10.31426/ijamsr.2020.3.6.3413

concerns. The most old ecological annoys and perspectives of the day are reestablished by their virtuoso. Eco-criticism, today, has transformed into a celebrated enunciation inside and without academic circles any place all through the world concentrating on its reasonable target of environmental consideration. All things considered, such works can just mix one's psyche without setting up a reliable affiliation. It is just the innovative compositions of incredible authors and their energized interest that can influence the pursuers into stirring up an extraordinary chat with nature. The innovative framework has even meandered in by observing 'ecocriticism' as a particular piece of input. Numerous artists, authors and story scholars have shown a solid detestation for the moving tide of present day legitimacy and love of machines by exhibiting their pressure and true blue sensitivity through their distinguishing strength. As Ruskin Bond puts it, 'The ecocritic needs to follow environmental insights and delineations any place they seem to see basically more without a doubt a typical conflict which is evidently occurring, from time to time part verified, in a noteworthy number of social spaces. The majority of all, eco-criticism endeavors to review compositions and thoughts to the degree their clearness and solace as reactions to environmental cries.

In any case, crafted by Ruskin Bond stands separated, as in his guiltless kids' stories appear to interlace the hour of youth and space of Nature so as to not seem, by all accounts, to be direct lobbyist literature-rather it inconspicuously lights up the Eco-critical viewpoint intrinsic in the entirety of his works. Ruskin Bond, being the author of in excess of 500 expositions, stories, and poems and in excess of 50 books, it is fascinating to take note of that Nature is the default scenery of countless his literary works. Truth be told, in Ruskin Bond's works, Nature doesn't just capacity as the phase where all the activity is performed, "yet as an actor in the drama"

Not being a singleton hypothesis, Eco-criticism has different strands that infiltrate into different sub-fields of eco-cognizant examinations. Additionally, the comprehension of Ecocriticism has been helpfully characterized into three waves as relevantly explained by Derek Gladwin in first experience with Eco-criticism: the first underscoring on a "celebratory methodology of wilderness and nature composing." The second wave was worried 
IJAMSR 3 (6) www.ijamsr.com CrossRef: https://doi.org/10.31426/ijamsr.2020.3.6.3413

\section{International Journal of}

Advanced Multidisciplinary Scientific Research (IJAMSR) ISSN:2581-4281

about "speculating and deconstructing humanfocused grant in eco-studies; government and ecological corruption; office for animals and plants; sexual orientation and race as ecological ideas; and issues of scale." The third wave had concerns like global warming just as post expansionism.

\section{The Collection 'The Ecocriticism Reader'}

Similarly as feminist analysis analyzes language and literature from a gendercognizant point of view, and Marxist analysis brings a consciousness of methods of generation and economic class to its readings of the texts, eco-criticism adopts an earthfocused strategy to literary examinations.

Ruskin Bond said in an ongoing meeting, "I don't generally compose expertly or for money. It is something I believe I need to do to relate my impression in the everyday life that I see around me. I have chosen following three short stories here for the eco-basic examination in this paper:

- No Room for a Leopard

- $\quad$ Growing Up with Trees

- $\quad$ Dust on the Mountain

\section{No Room for a Leopard}

'No room for a Leopard', is about deforestation and it's going with outcome. It exhibits the disgraceful state of the animals after deforestation. It is an extremely moving record of the killing of a confiding in leopard by a gathering of shikaris. Due to deforestation occurring in the hills and encompassing regions, numerous animals have been crashed into the valleys occupied by people. This opens them to grave dangers and deadly experiences - one such experience has been depicted in this story. The story additionally uncovers the distinction between the youngsters' reasoning and the adult reasoning has likewise been brought out. Kids love nature. They love every one of the animals. It easily falls into place for them. No ulterior thought enters their innocent minds. They can never under any circumstance consider hurting the animals or abusing them for their own benefit or profit. Yet, the adults are exclusively determined by soldier of fortune contemplations. In the event that a leopard's skin can get them a decent value, they would not reconsider before killing him. Empathy, trust, adores... these make no difference to them. A charming world stands broke due to this childish mercilessness. 
IJAMSR 3 (6) www.ijamsr.com CrossRef: https://doi.org/10.31426/ijamsr.2020.3.6.3413

\section{International Journal of}

Advanced Multidisciplinary Scientific Research (IJAMSR) ISSN:2581-4281

\section{Growing Up with Trees}

A nearby take a gander at the short story "Growing Up with Trees" recommends that Ruskin Bond has endeavored to depict the utilitarian part of trees in his neighborhood in the light of the way that they contribute towards the prosperity of humans by giving fruits as well as giving safe house to birds, animals, and insects of different sorts. It additionally gave little Ruskin Bond a trunk to move upon. A portion of the liberal trees were likewise home to bumble bees who constructed their brushes on the branches consequently being valuable to animals and humans too. Bond depicts warmly and at length with the portrayal of his preferred trees and birds. He appears to be especially attached to jackfruit and banyan trees.

This short story is all the more properly a devoted depiction of the all-swarming biodiversity and doesn't appear to pursue the regular starting center end approach of a story account. As it closes, Bond utilizes amusingness to clarify his delicate connections with the birds and insects dwelling on the trees:

A woodwind in my grasp, I would have a go at adding my shrill piping to theirs. Be that as it may, they thought inadequately about my musical ability, for at whatever point I played on the flute, the birds and insects would die down into a tormented and puzzled quiet.

It is astounding that he believes birds and insects to be clear creatures and doesn't reject them as animals having a place with lower strata in the ecosystem. They are given due love in the entirety of his short stories. They are practically similar to dearest companions to him.

\section{Dust on the Mountain}

'Dust on the Mountain', centers around Bisnu, a kid, whose quest for work empowered him to become familiar with the significance of trees. In this short story Ruskin Bond develops as an environmentalist clarifying the significance of trees a significant characteristic of his stories managing environmental concern. Bisnu's place is appeared accordingly to get no rainfall as the result of merciless deforestation. Other than deforestation, trees have died and are dying because of our imprudence, as well. The campers make a fire and neglect to douse it which now and again becomes the reason for immense fire. 
IJAMSR 3 (6) www.ijamsr.com CrossRef: https://doi.org/10.31426/ijamsr.2020.3.6.3413

Along these lines, a large number of Himalayan trees died in the blazes. Oaks, deodars, maples, pine trees that had taken a very long time to develop get now heartlessly harmed and demolished in the fire. There was nobody to douse it. It brings days to subside without anyone else. Because of this recklessness on individuals' part, numerous important trees are lost. Despite the fact that such episodes are basic on the Himalayas yet individuals have not taken in the exercise and neglect to carry out their responsibility without understanding that it is they who will be influenced of such acts. Toward the finish of the story both Bisnu and Pritam understood the significance of nature after Pritam the truck driver made due from genuine mishap on the mountain road because of a tree on road. They comprehended the importance of developing trees and defending their own quintessence as well as family.

Dust on the Mountain was first distributed in "Dust on the Mountain - Collected Stories" in 2009. The stories, 'The last Truck Ride' and 'Dust on the Mountain', have a lot of closeness. As a matter of fact the subsection V (p 497) to VII (p502) of 'Dust on the Mountain' is nearly equivalent to that of 'The last Truck Ride' with the prominent special case of the principle character's name being Nathu in the first and Bisnu in the last mentioned.

\section{Literature Review}

A Garland of Memories, (2014) The Ecocritics opine that expanding people is especially hazardous for the protection of the trademark assets. The developing energy of land because of the stretching out masses engages the pioneer to separate down the trees and make the land open, without knowing the results. Thusly, spreading of deserts, Ecocritics trust, that for the flourishing of a nonhuman life, sizeable diminishment of human people is fundamental In the prior conditions man considered himself to be the bit of nature; presently he is the exploiter of nature. This hardness makes certain to boomerang on him.

Oakes and Price, (2016) without a doubt a champion among the most dominant employments of nature, since the late eighteenth century, has been in this specific sentiment of goodness and chastity. Nature has inferred the open country, the flawless spots, plants and animals other than man. The use is especially present in contrasts among town and nation: nature is what man has not made, 
IJAMSR 3 (6) www.ijamsr.com CrossRef: https://doi.org/10.31426/ijamsr.2020.3.6.3413

\section{International Journal of}

Advanced Multidisciplinary Scientific Research (IJAMSR) ISSN:2581-4281

anyway if he made it adequately long back a hedgerow or a desert it will generally be joined as normal.

Further, Raymond Williams, (2015) says that nature is something that is there for man to acknowledge, understanding and use yet he doesn't have the ability to make nature. Its security depends on the way of life of the spot. Or then again, the way of life of the spot makes according to environment or the nature, as Darwin has proposed the theory of the 'survival of the fittest'. The people who alter well as demonstrated by nature can survive happily on this planet and Ruskin Bond's stories are the perfect instance of this since his characters moves according to the need of their condition. Along these lines, we can express that nature and culture are interrelated. In the obsolete conditions it was believed that by turning one has come back to nature one destroys all of the conceivable outcomes of complete augmentation and profound development.

Elamparithy, (2015) In any case, these days, Nature is a champion among the most usually talked word. When the remarkable etymologist, Julia Kristeva, composed a book entitled Language - The Unknown wherein she has said that, "Vernacular is everywhere anyway our cognizance of it is generally next to nothing. In a comparative vein, nature is also not at all observed anyway we are in nature, some bit of nature and included by it all around."

Manoram Sen (2017) The India government has recognized his innovative virtuoso. He was granted the esteemed Padma Shri grant (1999), and Padma Bhusan grant (2014) for his commitment to Indian English literature. Bond is an enthusiastic admirer of life however it isn't liberated from death, partition and difficulties. The way of thinking of life as reflected in his work may be "to endeavor, to look for, to discover and not to yield". His sharp perception incorporates the sensitive universe of the kids, the diverse shades of Indian life, the hoisting and alleviating regular world, and love in the presence of each living creature. The present paper centers around Ruskin Bond's major thematic worries in his short stories. In this paper, Bond's humanism has additionally been analysised in the scenery of his thematic example.

\section{Ecocriticism}

What ... is ecocriticism? Basically, ecocriticism is the investigation of the connection among literature and the physical 
IJAMSR 3 (6) www.ijamsr.com CrossRef: https://doi.org/10.31426/ijamsr.2020.3.6.3413

\section{International Journal of}

Advanced Multidisciplinary Scientific Research (IJAMSR) ISSN:2581-4281

environment. Similarly as feminist analysis looks at language and literature from a gendercognizant point of view and Marxist analysis brings a familiarity with methods of creation and economic class to its perusing of text, ecocriticism adopts an earth-focused strategy to literary investigations'

Ecocriticism as a get ready lays exceptional feature on the authors who frontal zone nature as a basic piece of their subject and feature ecocentric estimations of reasonable improvement, complete good duty, and the examples of the world past ourselves, that is, the non-mindful, the non-human world. The term is the most youthful of the revisionist improvements that got vitality because of the spreading out environmental emergency, controls the investment's among humans and their common condition. This endeavor has been encircling the earth by being a specialist of nature. To refer to Meera Subramanian:

"In the sum of their assortments, these parts outline the world we all in all occupy. They play off one another in a perpetual move of concordance. Be that as it may, human impacts have continuously toppled this natural modify. Today, equipoise among the segments is disintegrating, and if these ecological troubles are not individuals and untamed life will continue enduring. India has transformed into the organizing ground for a preliminary in human survival."

Ruskin Bond fabricates nature by utilizing joining legends, experience, dreams and history to uncover human coordinated effort with the non-human world. It additionally makes an endeavor to locate his discerning duty with thought concerning advancing toward cataclysm of the overall condition. Eco-critical approaches make assessment concerning the relationship among nature and human culture and sit in addition sees at what minute the makers address its assets. The entire of the ecosphere where vitality, matter and examinations go to cooperation is the commence of eco-criticism in the social world.

\section{How Ecocriticism Differs From Other Approaches}

Literary theories ordinarily look at the relations between writers, texts and the world. In a large portion of the literary theories, the world is synonymous with society that incorporates the social sphere. Eco-criticism extends the thought of the world to incorporate the whole ecosphere. We can say, it is an investigation that steps by step moves from inside to outside. 
IJAMSR 3 (6) www.ijamsr.com CrossRef: https://doi.org/10.31426/ijamsr.2020.3.6.3413

Eco-criticism keeps on extending past its American beginnings, with work being done in Canada, the United Kingdom, Australia, New Zealand, Japan, Korea, Europe and India among others.

\section{Ecocriticism As A Literary Theory}

For the most part, the conventional theory thinks about the semantics or the social foundation or the social foundation as a significant factor, eco-pundits accepts nature as a prevailing factor as they accept that our development as a general public is to a great extent subject to the powers of nature. Since, as indicated by them, the world where we live isn't made distinctly with the language and social elements.

It is just one of the numerous factors liable for the presence and advancement of humans. Life including the human life is vigorously influenced by the job nature and environment plays and therefore nature is the most significant thought of this theory.

In the wake of changing over into the field of theory, the green criticism was part into parts and one section created itself as a branch committed to rehashing and breaking down the job of nature, portrayal and the common elements in the literary works delivered by the researchers from the worldwide. Green examinations are only the territorial literature as it contemplates the distinctions of nature in better places. Be that as it may, the focal wellspring of musings, research, and discoveries in this field will consistently be the authors and writers surely understood and built up in the world of literature.

\section{Conclusion}

Bond's short stories, characterized by its direct language, rich beginning and critical significance, are for the most part invited by readers. In any case, customary readers and critics just notification that his stories reflect a specific connection between human creatures and nature, however they neglect to indicate what relationship it is, not to mention the writer's ecological awareness suggested in the stories. As a matter of fact, in such an ecological-emergency ridden time, it is reasonably critical to break down Frost's ecological awareness, as he is still generally read even today. ' 'No space for a Leopard', 'Growing Up with Trees' 'Dust on the Mountain' are about the extraordinary chain of being which ties man and nature, as in the chain of ecosystem, demonstrating reliance and 
IJAMSR 3 (6) www.ijamsr.com CrossRef: https://doi.org/10.31426/ijamsr.2020.3.6.3413

comprehensiveness which underlines on the eco-friendly, cohabitative and symbiotic connection among man and nature.

\section{References}

1) A Garland of Memories Indian Writing in English. New Delhi: Swastik Publications Print.

2) Oakes and Price (2016) Wordsworth Literary Criticism. London: Routledge \& Kegan Paul, 1974. Print.

3) Raymond Williams, (2015) The Ecocritical Psyche: Literature, Evolutionary Complexity and Jung. London: Routledge, 2012. Print.

4) Elamparithy, S. (2015) "From Waste Land to Wonder Land: The Psychology of Ecodegradation and the Way Out". Contemporary Contemplations on Ecoliterature. Ed. Frederick, Suresh . New Delhi: Authors Press. 132. Print

5) Sen, Manoram. "Thematic Preoccupations in Ruskin Bond's Short Stories: An Evaluation". IJELLH Journal, Volume- v. Issue- vii. 2017.

6) Gladwin, Derek. "Ecocriticism." Oxford Bibliographies, Oxford University Press, 5 Jan. 2018, www.oxfordbibliographies.com/view/d ocument/obo9780190221911/obo97801902219110014.xml.
7) Bond, Ruskin. The Essential Collection for Young Readers. Red Turtle, Rupa, 2016

8) Garrard, Greg, ed. The Oxford Handbook of Ecocriticism. New York: Oxford University Press, 2014.

9) Glotfelty, Cheryll, and Harold Fromm. The Ecocriticism Reader: Landmarks in Literary Ecology. University of Georgia Press, 2009.

10) Hawkins, R. E. (2015). Jim Corbett's India. New York: Oxford University Press, Print. 